\title{
En el territorio de la incertidumbre: entrevista, poemas y comentarios de autolectura.
}

\section{(In the Territory of Uncertainty: Interview, Poems and the Author's Own Comments)}

Tomás Sánchez Santiago ${ }^{2}$

Comunidad autónoma de Castilla y León (España)

\section{Carlos Francisco Monge ${ }^{3}$}

Universidad Nacional, Costa Rica

\begin{abstract}
RESUMEN
Entrevista sostenida con el poeta español contemporáneo Tomás Sánchez Santiago, autor de una considerable y variada obra literaria, que pasa por la poesía, la narrativa, la crónica y el ensayo. En la conversación se trata una amplia gama de asuntos: desde la formación de un escritor hasta las múltiples instancias que el ejercicio literario afronta en una sociedad occidental contemporánea. El escritor distingue entre el papel social de la literatura, en nuestros tiempos, y la defensa de la palabra, siempre con voluntad estética, como espacio y conciencia ante las circunstancias que marca la convivencia, al margen de expectativas de otra índole. La poesía - sostiene- es radicalidad, exploración de sentidos y compromiso con la propia esencia de la palabra: desvelar lo oculto, desordenar para alcanzar otro orden, otra dimensión más rica y llevadera. Se añaden al pie notas y datos aclaratorios, de parte de quien guio la entrevista, así como una selección poética y comentarios a ella del propio escritor.
\end{abstract}

1 Recibido: 10 de julio de 2020, aceptado: 1 de setiembre de 2020.

2 Poeta y escritor independiente, de la Comundad de Castilla y León, España. Correo electrónico: tosansan@gmail.com

3 Escuela de Literatura y Ciencias del Lenguaje. Correo electrónico: cfmonge@hotmail.com

LETRAS 69 (2021), ISSN 1409-424X; EISSN 2215-4094

DOI: http://dx.doi.org/10.15359/rl.1-69.7

www.revistas.una.ac.cr/index.php/letras 


\begin{abstract}
Interview with the contemporary Spanish poet Tomás Sánchez Santiago, author of a considerable and varied literary work, which includes poetry, narrative, chronicle and essay. The conversation covers a wide range of issues: from the development of a writer to the multiple instances that literary practice faces in contemporary western society. The writer distinguishes between the current social role of literature and the defense of writing, always with an aesthetic will, as a space and awareness of the circumstances of coexistence, regardless of other expectations. Poetry, he maintains, is radicalism, exploration of the senses and commitment to the very essence of the word: unveiling the hidden, disorganizing to achieve another order, another richer and more bearable dimension. Notes and explanatory data from the person who guided the interview are added, as well as a poetic selection and comments by the writer himself.
\end{abstract}

Palabras clave: literatura española, poesía española contemporánea, papel del escritor, literatura y sociedad, memoria y escritura

Keywords: Spanish literature, contemporary Spanish poetry, role of the writer, literature and society, memory and writing

Tomás SÁnchez SANTIAgo es un poeta español contemporáneo, nacido en Zamora en 1957 y afincado desde hace tres decenios en la ciudad de León. Su obra literaria, de considerable extensión, es muy variada en géneros, registros discursivos, temas y tipos de lectura. $\mathrm{Su}$ obra poética, que empezó a publicar en 1979 abarca hasta la actualidad siete libros, que ha reunido recientemente en el tomo Este otro orden (2019), a los que habría que añadir dos antologías publicadas con anterioridad (Detrás de los lápices y Cómo parar setenta pájaros). En el campo de la narrativa ha publicado siete obras, algunas entre novela y crónica, todas de nutrida riqueza de asuntos y, como queda dicho, variedad de registros. Mediante su obra ensayística, han ocupado muchas de sus páginas temas y autores de la poesía española del siglo xx y varias ediciones críticas. Además, Sánchez Santiago colabora ocasionalmente con artículos en la prensa. Parte de ellos aparecieron bajo el título Salvo error u omisión, en 2002. A su novela Calle Feria se le acreditó el Premio de Novela Ciudad de Salamanca, correspondiente a 2006, y a 
Años de mayor cuantía el Premio Tigre Juan y el Premio de la Crítica de Castilla y León, en 2018. Con la fotógrafa Encarna Mozas publicó un libro híbrido de textos e imágenes, Interior acuario, en 2016. Acaba de aparecer, en Salamanca, un tomo Abordajes, de intervenciones críticas sobre educación, historia, arte y fotografía.

Esta entrevista que ofrece LETRAS se forjó sui generis, gracias a la superación de la distancia territorial que permiten los medios audiovisuales de la tecnología contemporánea. Una experiencia singular, porque al huésped y al anfitrión solo les bastó corroborar sus intereses comunes en torno a la situación y posibilidades del arte y la literatura en la cultura contemporánea. La entrevista sostenida se concentra en ciertos asuntos de la situación actual de la poesía de hoy, escrita en español, tanto en España como en Hispanoamérica. Las notas al pie son responsabilidad de quien fungió como entrevistador. He aquí el diálogo sostenido. Como cierre, el poeta seleccionó varios poemas suyos, a los que añade valiosos comentarios, a modo de autolectura, fuente de singular interés para futuros estudios de su obra.

Empecemos por esto: ¿cuánta importancia le das a lo relacionado con tus propios origenes, al papel que desempeña la memoria en tu escritura?

Cuando nací en 1957, Zamora era una pequeña ciudad ya amenazada por el abandono, por la indiferencia de las instituciones hacia ella. No sé si la capital tendría entonces más de 40.000 habitantes. Y su medio preferente de sostén económico era la agricultura y la ganadería, además de un comercio abocado a esos ámbitos. Nada de tejido industrial. Por los años 60 se empezó a configurar una España disimétrica cuyas consecuencias se están pagando dolorosamente ahora con esa «España vaciada» de la que se habla con insistencia justamente cuando ya es irremediable cambiar las cosas. Haber nacido ahí, en una provincia de fuerte raigambre ancestral, sin el asalto de la modernidad en casi ningún aspecto, a mí me vino bien para ciertas 
cosas: por ejemplo, el lenguaje que escuchaba entre los zapateros que iban a comprar a la tienda de mi padre, en la calle Feria ${ }^{4}$, desde sus respectivas comarcas. Para mí era un goce escucharlos hablar de cuestiones del oficio o del campo; muchos de ellos complementaban su oficio de zapatero con labores campesinas. Ellos me pusieron el oído alerta. Estoy seguro de que su relación elemental y directa con las palabras influyó decisivamente en mí.

Entonces procedes de una estirpe de comerciantes...

Tanto por vía materna como paterna, yo vengo de una casta comerciante, sí. Mis antepasados maternos creo que eran judíos, establecidos en La Raya ${ }^{5}$ portuguesa, una zona donde se escondieron aquellos criptojudíos ${ }^{6}$ que no desearon irse de España. Mi abuelo fue ferretero, establecido luego en Alcañices, pueblo fronterizo con Portugal; en cuanto a los orígenes paternos, provengo de Villarramiel, un pueblo castellano de Palencia ${ }^{7}$, famoso hasta no hace mucho porque en él se dedicaban a curtir las pieles. Mis bisabuelos y mis abuelos eran «pellejeros», así s eles denominaba. Una vez que pregunté a mi padre me dijo que había oído que sus abuelos eran «coseros», que andaban de acá para allá con sus carromatos vendiendo y comprando diversos géneros (coseros es una palabra que luego encontré que ya se decía en el siglo XVI, en alguna obra de María de Zayas ${ }^{8}$ ). Creo que eran arrieros o buhoneros. No sé. Pero siempre vinculados al comercio. Luego fue mi abuelo quien se estableció en Zamora para

4 El escritor se refiere a una calle del centro histórico de Zamora, relativamente cercana al río Duero, que atraviesa la ciudad. Es el tema central de una de sus obras homónimas, Calle Feria (Sevilla: Algaida, 2006; $2^{\mathrm{a}}$ edición, La Isla del Náufrago, 2014), como se verá más adelante. (N. de la E.)

5 La Raya es un nombre coloquial para referirse a la frontera terrestre acordada entre España y Portugal.

6 Se llamaban criptojudios a aquellos que quedaron escondidos, disimulados más bien, en el territorio de La Raya. Aunque se incorporaron a la vida cristiana y española, no dejaron de mantener su fuerte identidad.

7 Villarramiel: localidad y municipio al norte de Zamora, en la provincia de Palencia.

8 María de Zayas (1590-1647), escritora española situada históricamente en el denominado Siglo de Oro español, autora de unas célebres Novelas amorosas y ejemplares. 
poner una tienda de curtidos. Allí vivimos, en la vivienda de encima del pequeño comercio de la calle Feria. Una casa de dos plantas llena de incomodidades. Pasábamos frío, como todos por entonces, y yo particularmente, miedo. Mi infancia fue una infancia de sombras, de sustos, de sensaciones de inminencias que me acosaban... Eso está reflejado en la atmósfera de mi libro de poemas $E n$ familia $^{9}$ y en algún relato de Calle Feria y de Años de mayor cuantía $^{10}$. Todavía me estremezco cuando pienso en aquel caserón, donde mis padres vivieron hasta 1976. Por mi parte, me fui a estudiar a Salamanca en 1974. Y ya volví a esa casa solamente de manera accidental. O sea, que a partir de mis 17 años me fui desvinculando progresivamente de la ciudad y de la familia. Enseguida aprobé una oposición de profesor y me fui a Algeciras ${ }^{11}$, que era el lugar más alejado de Zamora que encontré. En el fondo, tenía el deseo de no dejarme apresar por la ciudad, un tanto sofocante, como todas las ciudades pequeñas. Luego ya la vida vino por su cuenta baqueteándome más o menos, como a todos; pasé once años en Burgo de Osma, en la provincia de Soria ${ }^{12}$, dando clases hasta que aterricé en León con mi familia en 1993. Una ciudad cómoda, agradable para mí — su provincia es maravillosa-, con amigos que han ido creciendo en número y un ambiente cultural vivo, nada atosigante; al menos, así lo percibo yo. Y aquí me quedé. Hasta hoy.

Naciste en Zamora y hoy día vives en León, desde hace muchos años. Tu primer libro aparece en 197913, y desde entonces lo han sucedido muchos, y de muy variados géneros. ¿Cómo fue tu formación literaria, en aquella veinteañera edad?

Fui un producto de mi época, como nos ocurre a todos. Teniendo en cuenta las circunstancias de aquellos años, diría que fui un aprendiz

9 En familia (Valladolid: Fundación Jorge Guillén, 1994).

10 Años de mayor cuantía (Madrid: Eolas Ediciones, 2018).

11 Algeciras, ciudad española en la provincia de Cádiz, al sur de España.

12 Soria, provincia castellana, limitante ya con Aragón.

13 Amenaza en la fiesta (Salamanca, 1979). 
a ciegas de casi todo. También de lo que concierne a la lectura, lo cual no es del todo malo porque, además de naufragios y de itinerarios poco fiables, la curiosidad sin prejuicios se iba imponiendo a todo. O sea, que leía todo lo que caía en mis manos, fuese lo que fuese. Recuerdo novelas de aquellas llamadas edificantes — qué gracia me ha hecho siempre esa palabra - dirigidas a los jóvenes. Libros de Martín Vigil, Torcuato Luca de Tena, Luis de Castresana... ${ }^{14}$ autores de alcance moral, a fin de cuentas, que tenían cierto nervio narrativo. Me recuerdo alternando esas lecturas con otras de Baroja, Miguel Delibes, Aldecoa - sus relatos magistrales, que aún leo-y, sobre todo, Stevenson. La isla del tesoro me arrebató como ningún otro libro lo ha hecho hasta ahora, como ya he contado numerosas veces.

En cuanto a la poesía, me entró enseguida por el oído el hechizo, el magnetismo inigualable de las palabras por sí mismas. Eran solo versos aislados, pellizcos de algunos autores. Los que venían en las enciclopedias escolares, los que podía encontrar en casa: Garcilaso, Bécquer, Antonio Machado, Rubén Darío, Juana de Ibarbourou, la parte más previsible de la generación del $27 . .$. Eso bastaba para dejarme cautivo de las palabras. Antes de los veinte años descubrí tres voces que me dieron un revolcón definitivo. Fueron Neruda, Miguel Hernández y, sobre todo, Claudio Rodríguez. Leyendo a Claudio fui entrando en la modernidad poética de entonces. Por una parte, descubrí a otros autores coetáneos suyos como Valente o Brines; por otra, autores como Baudelaire, Rimbaud o Rilke. Así me fui orientando, con golpes de timón inesperados. No había otra manera entonces, viviendo en una pequeña ciudad de provincias como yo. Ni siquiera en la universidad aprendí demasiado de aquellos profesores cavernosos, enclavados en autores y obras que iban repitiéndose curso por curso y cuyas maneras académicas distaban mucho del amor, de la pasión por

14 José Luis Martín Vigil (1919-2011), sacerdote jesuita español, autor de La vida sale al encuentro, Los curas comunistas y El sexo de los ángeles; Torcuato Luca de Tena (1923-1999), escritor y periodista español, autor de Edad prohibida y Los renglones torcidos de Dios; Luis de Castresana (1925-1986), escritor y periodista español, autor de El otro árbol de Guernica. 
las palabras. Desde luego, mi formación universitaria debe mucho más a compañeros que al profesorado, en general. Alguien como Ángel Campos Pámpano - el malogrado poeta y traductor, ya fallecido ${ }^{15}$ me descubrió a Pessoa, a Borges, a César Vallejo ..., autores que no se tocaban en los currículos de entonces o solamente se rozaban, como para cumplir con sus nombres y poco más.

Acaba de aparecer una edición de tu poesía reunida, Este otro or$\operatorname{den}^{16}$. ¿Dirías de tu propia poesía que ha evolucionado o ves en ella un universo unitario? No me refiero, claro, a aspectos de estilo ni de dominio del «oficio», mayor o menor, antes o ahora.

La reunión de una obra poética comporta una sensación extraña para su autor, al menos en mi caso. Cuarenta años ahí volcados, en esa ordenación lineal, cronológica, no dan idea de eso que se denomina «evolución poética». Creo más bien en otro tipo de idea de conjunto que se fundamenta, más que en una posible progresión lineal que pueda afectar a los contenidos o al estilo, en recurrencias retrospectivas, insistencias que rebrotan por su cuenta, obsesiones más o menos transfiguradas pero persistentes... Uno se da cuenta ahora, a estas alturas de la vida, de eso. En fin, esa es la perspectiva desde la que un autor puede atreverse a hablar de la configuración de su escritura poética. Pero hay algo más: siempre he aprendido mucho de los lectores. Sus impresiones a veces han sido verdaderas revelaciones para mí. O sea, que no tengo juicios prudentes ni sugestivos que ofrecer para hablar de Este otro orden. La unidad natural en la poesía, la que al menos para mí funciona, es el libro. Hasta ahí llego. La reunión en un volumen de toda la obra poética de alguien tiene un efecto práctico, es verdad, porque facilita esa posibilidad de tener «atrapada» toda la poesía de una vez. Pero entre libro y libro de poesía no hubo consecutividad, así que es engañosa esa inmediatez aparente. Siempre me ha parecido

15 Ángel Campos Pámpano (1957-2008), poeta y traductor español, autor de La ciudad blanca y La semilla en la nieve, entre otros.

16 Este otro orden: poesía reunida (Madrid: Editorial Dilema, 2019). 
que es difícil ponerse a leer la poesía completa de alguien. Exige estrategias de lectura para no caer en el empacho o en el aturdimiento. Ahora me lo debo aplicar a mí mismo.

Hablemos de tus filiaciones literarias. En alguna ocasión te has referido a tus lecturas de tres grandes núcleos poéticos: uno (que tendríamos que llamar clásicos), en el lejano Arquíloco; otro (clásicos modernos, digamos), con lecturas de los simbolistas franceses (Baudelaire, Rimbaud), y un tercero (por lo pronto, del siglo XX), con voces como las de Rilke o Paul Celan.

Sí, parecen bastidores bien distintos, ¿verdad? En realidad, en la formación lectora se producen asaltos de obras y autores que se quedan con nosotros por su cuenta. ¿Cuánto tiempo? No podemos decidir algo así. Precisamente, los arcaicos griegos me llaman mucho la atención por esa razón; esa escritura fragmentaria, esos retales de poemas que han quedado así, temblando azarosamente como para dejar patente la irónica lección de la vida: tanto escribir para terminar sobreviviendo solamente ciertos jirones inesperados. Y luego, eso otro, la indiscriminación entre la poesía, la física, la filosofía o la política en autores como Anaximandro o Solón. Por no hablar de Arquíloco, a quien citabas, que presenta el primer modelo de antihéroe en ese poema del soldado que tira su escudo para salvarse, algo impensable en el concepto griego del honor. O sea, que son arcaicos pero bien modernos, actuales del todo.

En cuanto a los otros nombres - Baudelaire, Rimbaud, Rilke, Juan Ramón Jiménez- son verdaderamente los fundamentos de la poesía que se despega sin remilgos de anteriores valores supuestamente obligatorios de mantener en el poema. No se me han desgastado. Los sigo leyendo. Sus versos están activos en mí.

Pasemos a la poesía española: ¿no te das como perteneciente a ninguna corriente o grupo literario particular? Les has dedicado estudios a varios poetas españoles contemporáneos (Carlos Barral, 
Antonio Gamoneda, Aníbal Núñez, José Ángel Valente) ${ }^{17}$. ¿Qué se puede decir, desde la actualidad, de poetas de esa talla?

Son dos cuestiones distintas. A la primera te respondo que no está en la mano del poeta eso de propiciar su adscripción a un grupo o a una corriente. No son propiamente suyas esas labores de empaquetado crítico. Al menos, debería ser así. ¿Por qué buscar la manada en algo tan solitario, tan incierto y personal como es escribir poesía? En la poesía española del siglo xx se dio muchas veces el fenómeno de autores que primero pugnaban por hacer piña con otros en una misma generación o grupo literario para conseguir visibilidad crítica y social; y cuando se lograba eso, entonces algunos se desgañitaban para desmarcar su discurso a toda costa del de los demás, argumentando que ellos no creían en asuntos grupales. ¿Por qué lo hacían? Porque al final el grupo se come al individuo; las adscripciones son fenómenos que corren el riesgo de simplificar todo a unos cuantos rasgos comunes que a menudo se aceptan a regañadientes por los poetas afectados porque no todos se reconocen en ellos. Son modos sutiles de hacer de la poesía un fenómeno social, una simplificación de alcance didáctico. Pero el verdadero poeta debe estar ajeno a su destino siempre. El poeta es un lobo solitario.

En cuanto a la segunda cuestión, citas autores que traté personalmente (salvo Valente, con quien solo me vi en una ocasión pero cuya obra me parece uno de los monumentos poéticos más admirables del siglo Xx). O sea, que hay fuertes razones de proximidad con Aníbal [Núñez], con [Carlos] Barral o con Claudio Rodríguez, sobre quien también he escrito algunas cosas. A Gamoneda lo sigo viendo con cierta frecuencia porque, al margen de nuestra amistad y de mi

17 Carlos Barral (1928-1989), poeta y editor catalán, autor de Usuras y figuraciones, Años de penitencia, Cuando las horas veloces; Antonio Gamoneda (1931), poeta español autor de una ingente obra poética entre la que figuran títulos como Descripción de la mentira, Blues castellano y Arden las pérdidas; Aníbal Núñez (1944-1987), poeta, pintor y grabador español autor de Definición de savia, Figura en un paisaje y Alzado de la ruina; José Ángel Valente (1929-2000), poeta y traductor, autor de Las palabras de la tribu, Interior con figuras, Al dios del lugar. 
admiración por toda su obra, vivimos en la misma ciudad. En todos ellos coincide una escritura que me sigue interesando desde diversas vertientes, incluida la que afecta a mi conciencia de ser habitante extrañado de este mundo.

Hablemos por aparte de Claudio Rodríguez ${ }^{18}$, quizá tu mentor más directo y quizá el de muchos más, que no lo conocieron pero lo han leído y lo siguen leyendo con atención y con pasión.

Entré en la poesía de Claudio Rodríguez muy pronto. Recuerdo bien aquel recreo lluvioso en el colegio - yo tendría a lo sumo 15 o 16 años, no más - cuando vi a un compañero de clase, Anacor Herrero, alguien excepcional por muchas razones, que estaba leyendo en los soportales del patio un librito. Le pregunté. Era Don de la ebriedad $^{19}$. Me invitó a leerlo y me quedé asombrado, arrebatado con esa apertura del libro que yo siempre he comparado a la apertura de La pasión según San Mateo de Bach o al inicio de las Elegías de Rilke. Ahí empezó todo. Luego leí todo lo demás y tuve esa ocasión de conocerlo, de compartir con él charlas sobre casi todo en esa frecuencia especial de la confidencia, de la cercanía vital. No es que fuese yo un amigo «de primera línea» de Claudio ni mucho menos. Pero yo creo que nos caíamos bien y hubo ocasión de hablar con él en diferentes ocasiones, de leer juntos en algún acto poético. Todo con muchas precauciones porque a Claudio no se le podía preguntar por nada relativo a lo suyo — me refiero a su poesía - a no ser que estuviésemos de antemano centrados en ello. No le gustaba sacar al poeta a relucir. «No seas cursi», decía con aquella voz levemente acatarrada, cuando se le preguntaba algo relativo a su poesía en medio de una juerga o mientras se daba un paseo con él por el campo. Él era así. Y, sin embargo, tenía una especial capacidad de control de un poema para leerlo, para gestarlo... esas labores de bodega que otros

18 Claudio Rodríguez, (1934-1999), poeta español nacido en Zamora, autor de Don de la ebriedad, Alianza y condena, El vuelo de la celebración y Casi una leyenda.

19 Don de la ebriedad (Madrid: Rialp, 1953). 
sacan a relucir con ímpetu profesoral. Yo creo que él se asustaba de su condición de poeta, que era algo que le excedía.

También he leído por ahi - a propósito de España, debo suponerque has afirmado que "vivimos en un pais altisonante, en que el murmullo es imposible en muchos ámbitos». ¿Vale eso también para la poesía de estos tiempos?

Vivimos en medio del ruido. Se fomenta el ruido deliberadamente. Y el ruido bloquea el pensamiento, la sensibilidad, la necesidad de otro tempo más delicado, necesario para la reflexión o para la contemplación sin vértigo. Eso es así, al menos en España. Los locales públicos - los bares, los supermercados, las tiendas y hasta las calles a veces - se inundan de estridencia musical innecesaria que no nos deja practicar ese arte cordial y extraordinario que es la conversación sosegada, con silencios intermedios y a media voz. Montaigne lo precisó muy bien. Ahora bien, no me atrevo a aplicar a la poesía actual esa misma sensación. Leo poetas que están en plena acción y hay de todo, claro. Me interesa esa poesía que mantiene en tensión al idioma aunque sea una tensión subrepticia, con un aparente voltaje de naturalidad que, sin embargo, inquieta a un lector como yo. No entro a valorar eso otro que pasa por poesía pero no es más que una efusión sentimentaloide o una serie de proclamaciones estentóreas y con rebabas sociales sostenidas con ritmo de rap, eso tan jaleado en los medios y en las redes sociales cultivadas por un público joven. Tanta complacencia mediática bastaría para desconfiar de esas maneras de maltratar el idioma. Las palabras de un poema contienen un resplandor oculto, se comportan «sin honores ni espejos», como tú mismo dices en tu revelador poema «Palabras», ¿no te parece?

En Hispanoamérica, durante cierto periodo del siglo pasado, se convirtió casi en un mandamiento escribir «poesía comprometida». Eso todavía sigue valiendo en no pocos casos (en particular en esta 
Centroamérica contemporánea). ¿Es la poesía, de suyo, una forma de compromiso?

La poesía conlleva antes que nada un compromiso con la radicalidad. La radicalidad del lenguaje, en primer lugar. Y también la radicalidad de una no aceptación de los maquillajes engañosos que emborronan el rostro verdadero de las cosas. La elementalidad es la forma extrema de la radicalidad y ahí acaba queriendo llegar con su escritura el poeta. Y es que la poesía debe comportar en su lenguaje tensión y verdad. Como dice Olvido García Valdés ${ }^{20}$, la poesía es «un lugar donde no se miente». En cuanto a esa otra concepción del compromiso, aplicado a una intención acusatoria, recriminatoria o en pos de la justicia social o de intenciones políticas, nunca he considerado la poesía como un itinerario necesariamente político ni un instrumento de denuncia; para eso ya están otros registros. A no ser que convengamos que todo es político - yo lo creo así: escribí un poema relativo a ello, titulado «Política» ${ }^{21}$ — y entonces sobran más explicaciones.

¿Es que al poeta, en cuanto tal, se le debe exigir utilidad y eficacia?

Claro que no. La utilidad, la productividad, la rentabilidad, la eficacia son exigencias de mercado, a la contra de todo lo que significa el fenómeno de la creación. El tiempo del poeta es otro, que nada tiene que ver con las expectativas sociales que sobre él pueden preverse. Baudelaire o Cernuda hablaban en sus poemas del ocio del poeta como algo necesario, connatural en él. Y Tomás Salvador González ${ }^{22}$ definió alguna vez la poesía como «lo contrario de lo útil». El poeta tiene derecho a la pereza; no se le debe exigir nada. Él es un extralimitado, alguien que vive en las afueras de lo convencional, incluso de lo conveniente: un forajido

20 Olvido García Valdés (1950), poeta española; su obra poética está reunida en Esa polilla que delante de mi revolotea (Madrid: Galaxia Guttemberg, 2008).

21 Pertenece a su libro El que desordena (2006).

22 Tomás Salvador González (1952-2019), poeta zamorano, autor de La entrada en la cabeza (1986), Favorables país poemas (1996), Divisoria de las aguas (2002) y la novela El territorio del mastín (2016), 
(de fora exitus) que mira el mundo de otro modo, muy distinto de la mirada convencional. Cuando ha optado por ser subsidiario de un régimen político, un partido, una ideología, etc., para sentirse útil glosándolos, su obra se ha resentido, se ha empobrecido. Neruda, que era en sí mismo ya un planeta poético y publicó demasiado, escribió aquel libro deleznable, Las uvas y el viento, dedicado a exaltar a Stalin. Y es que la creación - no solo poética - sucede fuera de los engranajes y las articulaciones de la sociedad. Pero la utilidad y la eficacia... dejemos esos conceptos fuera de nuestros intereses, no siendo que acabe creándose un Ministerio de la Poesía con sus funcionarios y sus edecanes. Sería horrible.

\section{¿Cómo se relaciona, entonces, el poeta con lo público?}

Ese concepto de lo público trae aparejado de manera natural otro: el de la falta de dominio sobre las cosas. O, dicho de otro modo, la sustitución del dominio por el servicio. Y el poeta nunca debería buscar el dominio sino la compañía; incluso la compañía de las palabras. Él no es el señor de las palabras; va a buscarlas, las saca con esfuerzo, escarbando, hasta llevarlas al poema, las emplea un poco a tientas, con una convicción nebulosa que, sin embargo, se las impone. Y las toma de cualquier lado. No hay palabras estrictamente poéticas. Todas lo son. El lenguaje es público, y como público que es no tiene dueño cierto. Esa es la relación más inmediata del poeta con lo público. Por analogía, él considerará que todo es público o debería serlo: no solo el sol, el aire, la temperatura, la lluvia, las nubes..., que son realidades que pertenecen a todos sin necesidad de hacer nada para merecerlas; también en la regulación de la sociedad apostará por lo público como último reflejo de una fraternidad que se ha disipado en aras de otras maneras de vivir dictadas por la competitividad, la voracidad social, la especulación... Pero esto ya es entrar en terrenos más complejos. Dejémoslo así.

Pero también has dicho -y eso se ve en tu poesía-, que el poeta no debe estar conforme, que es un rebelde; que el poeta desordena. Uno de tus titulos de poesía es ese: El que desordena. 
Claro. Es lo que antes venía diciendo. El poeta no se conforma con el orden del mundo, pervertido por muchos agentes que lo envilecen, desde el dolor o la muerte hasta la injusticia. Es una especie de Luzbel que se rebela contra todo lo que atenta contra la felicidad. Raúl Zurita habla de esa resistencia instalada en el corazón de las cosas que nos impide la dicha ${ }^{23}$. A desvelar la naturaleza de esa resistencia se dirige siempre el poeta. Por eso emplea ese lenguaje que se aparta de los lenguajes utilitarios y pone en juego otros factores de sugestión: el ritmo, la cadencia, el timbre... Factores que pasarán seguramente inadvertidos pero que en sí mismos configuran una propuesta a favor de la vida, de cómo debería ser la vida. Sí, esa versión del poeta como alguien que no cree en la placidez, en la complacencia, me interesa mucho, la tengo muy presente. Un poeta es alguien siempre desacomodado. Ni siquiera le sirve para ser poeta el lenguaje de los demás. Por eso sale a buscarlo a unas afueras que ni él conoce a veces.

También he leído en otra parte esta afirmación tuya: «La poesía es un ejercicio de ascética lingüistica». ¿Podrías extenderte?

Seguramente quería referirme a la condensación progresiva que exige la escritura poética. El itinerario de muchos poetas - pienso ahora en Antonio Machado o en Juan Ramón, que se iniciaron en las luminarias del Modernismo - va hacia esa depuración, ese ascetismo verbal, como si la decoración retórica ya no sirviera. También hay esos otros ejemplos de radicalidad extrema: Huidobro, Francisco Pino, Cirlot, Trakl, Celan... ${ }^{24}$ En ellos, la poesía acaba por identificarse con un residuo incinerado del lenguaje, incluso con un vacío absoluto, abismático. Son ejemplos de esa renuncia a la accidentalidad del lenguaje.

23 Raúl Zurita (1951), poeta chileno.

24 Francisco Pino (1910-2002), poeta español, autor de Espesa rama, Octaedro mortal o reloj de arena; Juan Eduardo Cirlot (1916-1973), poeta español, autor de Regina tenebrarum, Cosmogonía y Variaciones fonovisuales; Georg Trakl (1887-1914), poeta austríaco, autor de El otoño del solitario y Canción del fragmentado; Paul Celan (1920-1970), poeta alemán, judío-rumano, autor de La rosa de nadie, Compulsión de luz y Parte de la nieve. 
¿Como creador, te sientes igual cuando haces poesía que cuando escribes narrativa?

No exactamente. Pero no ocurre por deliberación mía. O sea, no me marco reglas estrictas de lo que debo y no debo hacer cuando escribo un poema o cuando estoy inmerso en una escritura de carácter narrativo. Es que yo creo que todo lo que he sabido escribir está empañado por la poesía. Sea lo que sea. Lo que sí puedo decir con más solvencia es que cuando escribo poesía hay una especie de asalto, de inmersión decidida en la entraña del lenguaje que lo hace todo más intenso y más incierto. Es como si uno estuviese cara a cara con el lenguaje, soportando el peso crudo de las palabras y su coloración sin apoyarse en nada más. No sé si acierto a explicarlo bien. En cambio, en la confección de un relato hay algo más. Una narración es como una escalera de interior con sus descansillos, sus escalones amplios, sus barandas para irse apoyando (ya sabes tú: la trama, la morosidad de una descripción, la aparición de un personaje que nos acompaña con su peripecia a través de lo narrado...); en cambio, la poesía es como una escalera de mano mal enclavada: vas subiendo, vas sintiendo el vacío bajo tus pies, no sabes dónde terminará... Hay más riesgo, más incertidumbre, más abismo en el poema. Vuelvo a emplear esa palabra tremenda: radicalidad.

Pasemos a tus novelas: Calle Feria, de 2006 y más recientemente Años de mayor cuantía, de 2018; ambas amparadas por importantes premios en tu pais.

Me decía un poeta amigo mío, con mucha sorna: «Hay que ver, Tomás, toda la vida escribiendo poesía y se te va a acabar mencionando por un par de novelas». Bueno, creo que los honores y los premios son bengalas fulminantes, efímeras. Hacen más visible por un rato las obras premiadas pero luego decae su atención y cada obra vuelve a quedarse sola, sin defensas exteriores. Debe resistir por sí misma, con o sin premios que la avalen. Yo agradezco mucho que se hayan 
fijado en esas dos narraciones - las únicas que he sabido escribir, por cierto- pero no creo que ello sea decisivo a la hora de considerarlas. Creo más bien en la soledad del escritor, alejado del ruido de la tribu, como estado natural. Por mi manera de ser, necesito regresar a mi penumbra particular cuanto antes a seguir escuchando el murmullo del mundo. Y eso he hecho también tras agradecer esos premios.

¿Está el escritor destinado a guardar la memoria de su época, de su entorno?; ¿no será un modo inconsciente de querer salvaguardar su propia biografia intima; existencial, digamos?

Hay algo muy curioso que ocurre en ese territorio de la memoria colectiva que parece misión exclusiva de los libros de historia o de documentos confesionales. Y es que hay ocasiones en que los libros de ficción, aun sin sujetarse escrupulosamente a los hechos y a los datos, dan idea de la atmósfera de una época con más rotundidad que aquellos otros. Quiero decir que si alguien quiere saber cómo era la España del siglo XIX debería leer los Episodios Nacionales de Galdós en vez de consultar tratados de economía o sociología de esa época. La verdad emocional está más cerca de esas novelas que de ese otro tipo de documentación objetiva y llena de certezas, sí, pero sin el aura que se precisa para entender el espíritu de la época. Es decir, respondiendo a tu pregunta, el escritor puede dar cuenta, en sus ficciones, en sus poemas, de algo que parecía destinado en exclusiva al registro de lo histórico. ¿Recuerdas aquello de Anna Ajmátova ${ }^{25}$ ? Cuando en la cola ante la cárcel de Leningrado, donde ella iba a ver a su hijo preso, una mujer desconocida la reconoce y le pregunta: «¿Puede usted contar esto?»; ella dice «Puedo». Y escribe Requiem. Y es que en situaciones extremas, donde la desesperación y el horror lo dominan todo, es la poesía la que puede dar cuenta del peso de la circunstancia. Eso mismo podría valer para la pandemia que aún nos invade. ¿Te das cuenta de

25 Anna Ajmátova (1899-1966), escritora rusa. Su obra poética Requiem la escribió entre 1935 y 1940; no se publicó hasta 1963. 
lo que ha sucedido? De pronto desaparecieron las certezas, nadie sabía atajar lo que estaba ocurriendo, el lenguaje de los políticos y de los economistas se desacreditó y el lenguaje de la ciencia aún no sabía despejar dudas sobre lo que estaba pasando. Y entonces, ¿a quiénes se ha pedido que hablen? A los filósofos, a los poetas. Su lenguaje se volvió de repente el más creíble.

Desde hace ya veinte años vienes publicando otras prosas menos "clasificables», a medio camino entre la crónica, el diario intimo, el artículo, la página de ocasión. Empezaste con Para qué sirven los charcos, luego Los pormenores, al que siguió La vida mitigada. Acabas de reunirlos en un tomo con hermoso título, muy poético, como no se podía esperar otra cosa de ti: El murmullo del mundo, en 201926. ¿Te fías más de la ambigüedad de los géneros literarios, como a tu modo también lo has hecho con tus novelas?

En su quehacer, el escritor es un ser impuro o debe estar dispuesto a serlo. Es decir, la transfusión de géneros es ya el género preeminente. En un poema puede encontrarse pensamiento explícito, una narración puede deslizarse hacia el registro ensayístico o incluso lírico... Yo al menos he operado así. Antes de publicar Años de mayor cuantía se lo pasé a un buen escritor, muy amigo mío, que me lo devolvió diciendo que a ese volumen le sobraban todas las páginas que no eran — digámoslo así- narración pura. Esa opinión bastó para que yo intuyera que debía dejarlo todo como estaba; él no entendía que en casi todos los relatos hubiese merodeos en torno al lenguaje ensayístico pero yo necesitaba hacer eso: contar algo desde una intersección de registros que se van cortando el paso, se van asaltando unos a otros. Siempre me sale así.

26 Para qué sirven los charcos (Badajoz: Los Libros del Oeste, 1999); Los pormenores (León: Los Libros de Camparredonda, 2007); La vida mitigada (León: Eolas Ediciones, 2014); El murmullo del mundo (Asturias, Ediciones Trea, 2019). 
No eres un escritor de multitudes o para multitudes. Le entregas tu trabajo a la editorial y, mediante esta, a la sociedad, pero no esperas que lo tuyo se convierta en un objeto de culto ni en mercancía para generar dinero, éxito o notoriedad comercial. ¿Cuánto ha afectado o puede afectar esa creciente aspiración al «éxito en ventas», que ha inundado de papel encuadernado los anaqueles de las grandes librerías?

Cuando el autor o la autora de un libro tiene como objetivo meramente el entretenimiento, tiene derecho a buscar el éxito social aparejado al éxito literario. Pero personalmente a mí eso no me interesa en absoluto. El verdadero escritor sabe que su último objetivo es siempre el fracaso («La próxima vez fracasaré mejor», decía Beckett). Volvemos a algo que hemos tratado anteriormente: el escritor no es una estrella del rock ni debe creer que necesita una multitud para arropar sus obras. Al contrario: no debe buscar público sino lectores. Su territorio es el de la incertidumbre. Es el último reducto de resistencia ante la tiranía de lo efímero, de lo vertiginoso en esta sociedad mercantil de recambios urgentes. Pero me temo que no todos piensan así. Y ello banaliza el quehacer de la escritura. Cuando veo en concursos de televisión preguntas sobre títulos de obras o nombres de autores caigo en la cuenta de hasta dónde ha descendido la importancia de la literatura: materia de diversión o de ganar unos euros por un concursante que fue en su día un escolar aplicado. La gente lo oye y dice: «iqué cultura!», porque recuerda nombres y títulos. Ahí hemos llegado, ya ves.

Desde tu perspectiva de escritor peninsular, refiriéndonos sobre todo a la tradición de la lengua con que hablas y creas, ¿cómo ves la literatura hispanoamericana, en particular su poesía?: ¿a quiénes has leído con más atención?

Ala poesía hispanoamericana le deberemos siempre la bocanada de aire fresco que a menudo se necesitaba por aquí cuando la poesía 
española estuvo lastrada, un tanto desecada por la retórica enfática, por las ínfulas nacionalistas, por la falta de osadía, por el ensimismamiento... Rubén Darío le dio el primer revolcón a lo que entonces se creía que eran los asuntos y las formas líricas preceptivos. Y luego llegaron Huidobro, Vallejo... Y después Roque Dalton, Enrique Lihn, Nicanor Parra, Olga Orozco, Blanca Varela... ${ }^{27}$ Todos ellos, entre otros, parecen saltar por encima de lo que presumiblemente se consideraba lo estricto poético. Van más allá, como si no les bastara tampoco el lenguaje asumido para la poesía. Hace poco descubrí a una poeta mexicana, Juana Adcock ${ }^{28}$, que lleva al extremo la lengua de sus poemas en Manca, un libro comprometido con el lenguaje y sin concesiones. Así que quiero pensar que el epicentro de la fuerza renovadora de la poesía en lengua española está todavía ahí, en América. Y eso debería tener un grado mayor de reconocimiento entre nosotros. Hace algún tiempo, en unas jornadas en torno al premio Cervantes, tuve ocasión de decir algo en público que venía pensando hacía tiempo. ¿Por qué ese premio se concede en años alternos a un autor español y a otro hispanoamericano? Un país contra un continente. No me encaja. A mí me parece un residuo del colonialismo español; una especie de resistencia a entregar el Grial. Debería corregirse esa actitud. Así lo dije en aquel momento. Y así lo sigo pensando.

¿Y qué decir de los narradores? Yo pertenezco a esa generación que despertó a la lectura consciente con Cortázar, Rulfo, Sábato, Borges, Onetti, García Márquez, Fuentes, Ribeyro... Ellos nos mostraron otras posibilidades de narrar a partir de modelos que los jóvenes no conocíamos —Faulkner, por ejemplo — o apoyándose en recursos cinematográficos. Aquellas maneras nos sedujeron a todos. Y nos abrieron un camino.

27 Roque Dalton (1935-1975), poeta salvadoreño; Enrique Lihn (1929-1988), poeta chileno; Nicanor Parra (1914-1918), poeta chileno; Olga Orozco (1920-1999), poeta argentina; Blanca Varela (1926-2009), poeta peruana.

28 Juana Adcock (1982), autora mexicana. 
Hiciste un estudio sobre el peruano Emilio Adolfo Westphalen ${ }^{29}$, poeta dificil y, en mi criterio, todavía sin el reconocimiento suficiente que su obra merece. ¿Te sentiste afin a su obra?

Durante un tiempo fui lector constante de Westphalen. Me magnetizaba su parquedad, su manera implacable de escribir, que en él casi era empezar a dejar de callar. Solo eso. Nada de expansiones. Entre otras cosas, supe por Westphalen que el poeta nunca debe abandonar del todo el silencio. Sus poemas son como emanaciones que ya no se pueden contener y salen a un exterior: unos cuantos versos y de nuevo al silencio. Esa fue la lección de Westphalen para mí, que creo que no aprendí muy bien.

Aquí, en nuestro medio académico —y en esta revista (LETRAS) para la que escribes - hemos avanzado en estudios de traducción. ¿Crees que una traducción llegue a afectar la obra original? Has dicho que las que se han hecho de tus poemas te lucen como «cuerpos extraños».

Bueno, esta última es una apreciación sincera, muy personal. No le hagas mucho caso porque tampoco se me ha traducido mucho. Pero cuando eso ha ocurrido y yo me acercaba a un poema mío trasladado a otra lengua era incapaz de entrar en su interior con suficiente comodidad. Me quedaba fuera. Fíjate. Es la misma sensación que me ocupa cuando publico un libro de poemas; incluso, cuando doy por terminado un poema. Me suena en una lengua extraña aunque sea la mía: una lengua inerte, eso es. Por eso, apenas leo poemas míos salvo en lecturas o recitales, claro. Pero es una sensación agridulce, como si también fuesen cuerpos extraños, como si tampoco fuera esa su lengua natural... Una cosa muy rara. No sé decirlo mejor.

En cuanto a la función de la traducción como posibilidad de intervenir sobre la obra traducida, estoy seguro de que en ocasiones

29 Emilio Adolfo Westphalen (1911-2001), poeta peruano, autor de Otra imagen deleznable, Máximas y mínimas de sapiencia terrestre y Ha vuelto la diosa ambarina. 
es así. Toda traducción comporta una pérdida, es verdad, pero si el traductor o la traductora han interiorizado la obra original, se han hecho con ella en esa zona indefinible que acaba por excitarnos, por sobrecogernos ante las palabras de otro, es probable que haya también una ganancia al transportarla a otra lengua, es decir, a otro espíritu, aunque no haya fidelidad filológica total a ella. Yo leeré siempre a Cavafis $^{30}$ en la traducción de José María Álvarez ${ }^{31}$ aunque me consta que hay otras más rigurosas, más apegadas literalmente al rigor filológico para con los poemas de ese autor. Las tengo, las traté de leer en su día. Pero no me funcionan. Y lo mismo me ocurre con los sonetos de Shakespeare: se pone como ejemplo la traducción, en clave rítmica, de Agustín García Calvo ${ }^{32}$. Y está muy bien, cómo no. Pero llegan las de Mújica Laínez o Carlos Pujol ${ }^{33}$ y les dan un aliento a esos poemas que no he encontrado en ningún otro traductor. Es como si de pronto esas piezas estuvieran escritas en nuestra lengua: esos traductores las hacen nuestras sin traicionarlas más de lo irremediable.

Cuando un poeta sostiene, como tú lo has hecho, que hay que preservar las palabras de la sombra del poder, ¿defiendes la independencia del creador o desconfias de las disimuladas cortapisas que ese poder suele imponer subrepticiamente?

Empezaré por decir que no existen sociedades no violentas. Todas lo son. Lo que ocurre es que — al margen de otros tipos de violencia explícita - hay una violencia sibilina, que no hace sangre y por eso parece que no existe. Es la violencia del lenguaje, el arma que ha sustituido con más eficacia a puñales y a pistolas. Arma de destrucción masiva; de seducción masiva, más bien. Así que ese uso

30 Constantino Cavafis (1863-1933), poeta griego, de una breve pero intensa obra lírica.

31 José María Álvarez (1942), poeta, novelista y ensayista español. Como traductor, ha efectuado valiosas versiones al español de Shakespeare, Villon, Eliot y, desde luego, Cavafis.

32 Datos de Agustín García Calvo (1926-2012), poeta, filósofo y traductor español. Realizó una ingente labor de traducción de los clásicos griegos.

33 Datos de Manuel Mújica Laínez (1910-1984), escritor argentino, traductor de Shakespeare, Moliere y Racine; Carlos Pujol (1936-2012), escritor, editor y traductor español. 
desprejuiciado y artero del lenguaje impregna los ámbitos sociales más requeridos por la atención. La política, la propaganda, la religión, los medios de comunicación..., todos los tentáculos del Poder suponen, para surtir su efecto, una perversión del lenguaje. Perversión de todo tipo. ¿Cuál será, en ese panorama, la misión del poeta, la misión del escritor? Preservar las palabras de esa contaminación. Volverlas a sacar de esos territorios tramposos y emplazarlas de nuevo en su lugar. Tú lo sabes bien: un poeta siempre busca, en todo lo que escribe, la inocencia de las palabras; las lava, las limpia, las repone en su sitio sin ruido. Es el país inocente del que hablaba Ungaretti ${ }^{34}$. Parece que nadie se dará cuenta de ello. Pero yo creo que sí. Su afán no es lograr algo nuevo con las palabras sino devolverlas al origen aunque a veces para ello haya que destruir, hacer arder el idioma, llevarlo más allá de los límites previstos, ahí donde no puedan tocarlo esos servidores de la ferocidad.

\section{SELECCIÓn POÉTICA Y AUTOLECTURA COMENTADA}

\section{Aprendizajes}

a Ángel Fernández Benéitez

Del espejo no el brillo de su azogue

ni el biselado donde se descompone en niebla

ciega la transparencia, sino el cartón

que empeña sin saberlo su oculta resistencia

en sostener a un tiempo

al cuerpo y a la luz, salvaguardando de la

caída de todo a un rostro, repitiéndolo

en el vilo encendido de un instante que cuelga.

De la estatua no el fuste, donde pudo

cuanto quiso el cincel. Ni la tarea

limpia del esmeril o de la gubia

34 Giuseppe Ungaretti (1888-1970), poeta italiano, autor de Sentimiento del tiempo, El dolor y La tierra prometida. 
ensayando maneras

de domar el espacio, darle un orden

mortal de cuerpo de inmortal belleza.

Más bien sentar los ojos allí donde

una piedra sustenta

al cadáver de mármol, y en que viven

letras leprosas que hablan desvergüenzas.

Y del beso (ah, del beso), no su voz, no su carne

sino que desmontarlo de nuevo a su inminencia.

(de La secreta labor de cinco inviernos, 1985)

\section{Primer comentario}

Siempre he considerado este poema como una suerte de poética que todavía me vale. Lo curioso es que no lo escribí con esa intención, al menos conscientemente. Lo digo más claramente en un texto que se publicó no hace mucho en Tropelías, revista gestada en la Universidad de Zaragoza: «Ahora ya no creo demasiado en las poéticas. En otro tiempo, sí. Me parecía, incluso, necesario tener una poética como quien tiene un patrón o una medida donde envasar estrictamente los poemas, que luego acababan derramándose por su cuenta. De modo que pronto supe que eran los propios poemas los que acababan por expresar - ellos mismos - las cualidades abstractas de lo que denominaremos mi pensamiento poético, caracterizado por una saludable provisionalidad, por el magma bullente de la misma inestabilidad de la vida. Porque ¿quién osa prever cómo va a ser dentro de un año? Análogamente, nadie sabe de qué ni cómo va a escribir. Nadie salvo quienes han aceptado plantillas previas a la hora de expresarse a fin de pertenecer a los coros poéticos dominantes (pero eso es otra historia). Por mi parte, otras veces he llamado la atención sobre el hecho común de pedirles poéticas precisamente a los poetas y no a los novelistas, a los pintores o a los dramaturgos. Como si debiéramos excusar con un equipaje teórico la crudeza del lenguaje que se supone tiene la poesía. O como si debiéramos dar pautas al lector sobre lo que sigue: si ello es oscuro, para orientarlo; si es explícito, para complicarlo con 
la construcción de pistas cruzadas que aturden definitivamente las aguas del poema. Por eso, las únicas poéticas ajenas que me sirven son aquellos poemas que son a la vez himno y doctrina; también el relato de algunas experiencias propias aparentemente inocentes que los poetas se lanzan a contar cuando les preguntan sobre su poesía. Hablaré un poco aquí de las dos cosas, en lo que a mí concierne.

En cuanto al poema, me sirve aún «Aprendizajes», que incluí en 1985 en La secreta labor de cinco inviernos. ¿Se me creerá si digo que no lo escribí con intención programática ninguna? Sólo después me di cuenta de que en él estaba contenida una mirada y una posición ante el mundo, que comenzaban por una negación frontal a lo consabido y que terminaban eligiendo las formas de lo inadvertido, de lo provisional, de lo intermedio como soluciones para despedazar las leyes de la corrección, que tanto han empequeñecido a la persona. «Sirvo para que las cosas se vean», dice Sophia de Mello, mi admirada poeta portuguesa. Y así sigue siendo: estoy convencido de que la poesía es el lenguaje que desordena la mirada y enseña a ver el resplandor de los seres y los objetos, un resplandor más allá de su función, de su utilidad lamentable, de su prestigio desteñido por el uso o por la reputación social que los clérigos del mundo puedan haberle otorgado $(\ldots)$ ».

Espero que el poema se explique no solo a sí mismo sino también mi posición ante el mundo: ensalzar lo inadvertido (el cartón y no el espejo; el pedestal y no la estatua; la inminencia y no el acto). Siempre he defendido esa mirada sobre lo inadvertido, sobre lo indefenso. Alguien una vez me hizo notar que hasta la estructura interna del poema respondía a eso. Por ejemplo, esa rima enmascarada, casi invisible, en los versos pares. Cuando lo oí, eso me gustó, me certificó lo que por intuición yo había hecho. 


\section{Mi padre se hace viejo}

Pues ya lo ves, Tomás, que con el tiempo

se desprende la fuerza de las piernas

y los ojos apuran hasta el ansia

el desastre moreno que es la luz

cuando se pierde la tarde. Es otoño

y no distingo bien en este tráfago

civil cómo tiritan las acacias

para acabar de perder su boscaje

de hojas que se retiran humilladas

a decorar la soledad de algunos

escaparates en invierno. Mira

qué difícil el pulso, y no consigo

labrar un sueño entero que me alivie

de la monotonía. Tengo miedo, además, cuando alcanzo noticias

de que tiempos menos benignos vienen

a enfriar las ciudades y a sus cúpulas

desestimarlas vientos que cuartean

los labios que educaron otros climas

más amables. Si vieras cómo tiemblo

cuando me quedo a solas con la casa

ahora, la casa chica donde hubo

pasiones lentas, carne asustadiza

que enderezaba un invisible cáñamo

debajo de las perchas, en el cuarto

de los baúles oscuros donde aún duran

libros de inmortal tinta y olorosa

escritura como aquel: Patres Principes.

Me cansan los asuntos, las rodillas

me arruinan si es que las lluvias percuten

como fustas de mimbre que en las tejas

decidiesen reunir en clamor sordo

otras aguas lejanas y hace tiempo

que el espejo me devuelve un deshielo:

el susto silencioso de las canas 
ensabanándome. Por más que hostigo

la memoria, todo lo allegadizo

se va volviendo menos, cruza un flujo

las cosas y las pone en retirada

mortal de color sepia (como aquellas

revistas de viajes que nos turbaban

las siestas en agosto y daban frío).

Así que ya lo ves, sólo sé nombres

(Francisco, Eutimia, Narciso, Carmina),

nombres que desenvuelvo y solo un rostro

común que los amuebla me contesta;

di tú cuanto he vivido, pon palabras

que enciendan otra vez años mojados

ahora por el olvido igual que leña

vana. Habla, pues, por mí. Di que es un pozo

que apenas atestigua, mi memoria,

mis labios nada pisan hace tanto

y empiezo a hablar de otro modo, hijo mío.

(del libro En familia, 1994)

\section{Segundo comentario}

¿Puedo decirlo? Mi escritura es movediza. Tanto en la poesía como en las narraciones (Calle Feria, Años de mayor cuantía). Quiero decir que a medida que se va perpetrando un libro, voy incluyendo en él materiales destinados previamente a otros lugares —o eso creía yo - pero que de pronto encuentran su sitio natural en otro depósito. He tenido la sensación de que a veces sucedía eso. Responde a mi convicción de que toda escritura tiene un carácter provisional. No creo en la fijeza de nada. En este caso, el poema esperaba al libro, y no al revés. Su gestación fue larga, lo tuve conmigo mucho tiempo en la memoria como quien tiene algo en un bolsillo que no quiere sacar a la luz. Era una cuestión sobre todo emocional. Mi padre aún vivía en 1977, cuando se me aparecieron por su cuenta los primeros versos. Él ya presentaba signos de la primera vejez aunque aún viviría quince 
años más. Pasó algo tremendo. Lo llamaron para ingresarlo en Madrid en un hospital para tratar su cáncer de riñón. Eso sucedió ¡el día que yo iba a presentar el libro donde, en primera instancia, iba a ir el poema! Aquel libro se titulaba La secreta labor de cinco inviernos. Pronto me di cuenta de que no era la sede natural de un poema con ese tono. Entonces esperé a escribir En familia (¿o lo escribí para incluir ese poema en él?) y supe que definitivamente debía ir ahí, junto a otros de la estirpe relampagueante de la memoria familiar.

Estuve mucho tiempo sin leerlo en voz alta. No podía. Lo intenté por primera vez en una lectura en Extremadura, a petición del poeta Álvaro Valverde, que me presentaba. No supe negarme pero entonces lo terminé de leer a duras penas, haciendo un esfuerzo y con la voz comprometida por la emoción. Era mi padre quien hablaba; no yo. Aquello podía conmigo.

Me interesan varias cosas del poema, que podrían aplicarse al talante general de mi escritura. Por ejemplo, eso de tomar voces prestadas (en Calle Feria y en Años de mayor cuantía eso es muy evidente), además de la insistencia en espacios y nombres que configuran mi memoria heredada. Esa casa donde viví, encima del comercio de curtidos; esos antepasados que despiertan mi curiosidad... Y aún hay otra cuestión: en los últimos versos, la voz de mi padre me hace un encargo («di tu cuanto he vivido, / pon palabras (...) habla, pues, por mí...»). Muchos años después, cuando me alejé lo suficiente de la vibración del poema, traté de obedecer a esa llamada escribiendo Calle Feria y un relato en Años de mayor cuantía titulado «Un recuerdo que no tuve» sobre sucesos de la vida de mi padre durante los días de la guerra civil. Era una deuda que quise solventar como pude; traté de cumplir con el encargo que se encierra en el poema «Mi padre se hace viejo». Me quedé tranquilo. 


\section{Como una insinuación}

Cuando escribes te manchas de ti mismo.

Y pones oscuridad y aire atacado

cuando respiras encima

de lo que nombras.

¿Es así?

Vas arrojando aliento de frente

a las palabras.

Una humedad violenta

las aleja como a un vuelo de aves insultadas

hasta la desorientación.

Eres el que ofusca. Eres el que atiende

las heridas con sal

y el que se remoja en las contradicciones.

He venido a por ti

entre lentas comadronas con la lengua rapada.

He venido a por ti

mas no entraré a buscarte.

Te espero en las afueras de los nombres, allí se han desalado

de sí mismos

y sólo continúa por sus huesos la sombra

de una música.

Esto ya no consuela, esto ya no consuela y debes aprender

otras maneras

de enjuagarte en los nombres,

como cuando se cruza un mercado

ya desmantelado

y sólo se propaga, por toda actividad,

la inversa inflamación

de desdecir.

(de El que desordena, 2006) 


\section{Tercer comentario}

Uno de los ejes de mi poesía es la preocupación por nombrar. El acto de «decir» comporta poéticamente una responsabilidad suprema para quien lo hace. De ahí que haya una especie de reproche, de insatisfacción. También la sospecha de que el yo, la voz que en el poema se expresa y lo ocupa esté demasiado pendiente de quien está detrás de ella («Cuando escribes te manchas de ti mismo»). Mi repelencia a ocupar demasiado espacio en cualquier circunstancia (incluido el espacio del poema) está muy presente en este poema. Y en otros, diseminados a lo largo de los libros que he publicado.

Otra cuestión: el poema es el último de El que desordena. Y la última palabra es «desdecir», una palabra que me gusta mucho por lo que puede llegar a significar. Ay, la profundidad de las palabras. No está puesto azarosamente en ese lugar terminal. Siempre que acabo un libro me parece que se me apagará la voz para siempre. Por eso parece sonar todo a despedida. Como si tuviera la certeza de no ser capaz de volver a escribir poesía nunca más porque ella se me iba a negar para siempre en la terminación de un libro. Es una obsesión que me ha perseguido siempre. He coqueteado con ella desde muy pronto. Recuerdo que en los años ochenta, antes de cumplir los treinta años yo, escribí un texto para rematar una lectura que se titulaba "Fin de trayecto". Allí explicaba que ya no sería capaz de volver a escribir. Hubo alguien - un catedrático de la universidad de Salamanca, presente en la lectura - que me riñó. Y tenía razón. Yo no tenía derecho a esas alturas de mi vida a creer que se me apagaba la voz. ¿Quién puede tener claro nunca eso? Dándole vueltas a todo ello, llegué después a la conclusión de que lo que me ocurría era que ya sabía que no podría volver a escribir esos poemas, precisamente los escritos hasta ese momento. Pero ya se ve que seguí insistiendo...

Por otra parte, «Como una insinuación» puede 'adherirse' al primer poema del libro siguiente, Pérdida del ahí, un poema que se titula «Toca, toca mudez», un título ambiguo - algo muy mío, también - donde parece hablarse de una resurrección a la poesía tras un 
tiempo en que «tocaba estar en la mudez». Si ves el último poema de Pérdida del ahí, mi último libro hasta la fecha, ocurre algo análogo. La pérdida de confianza en el nombrar.

\section{Tos en la noche}

Envuelta en latón sucio, perseguida

por perros y por piedras, golpea una tos la noche y su quietud

sin nombres

en la espesura textil de las habitaciones

(desollados,

los sueños han perdido color y valentía

y escapan entre lámparas sin ánimo

hacia la palidez).

Pero bajo ese estallido

seco

tú crees escuchar

el batido de otra palabra sorda, intermitente,

que aletea en el arrepentimiento

de una boca

con oscura insistencia.

La quieres retener un poco

más entre tus manos, como a un copo perdido

que algo pudiera ceder de su luminosa escocedura.

Pretendes

sujetar ese desbordamiento

hasta saber de qué,

de qué está hecho

su extravío vocal,

qué hubo antes de su desolación

metálica.

¿Se pierden para siempre 
las palabras que olvidamos?

No. No hay palabras retiradas del mundo:

su derrota es este encallamiento

último y espinoso,

tos que escapa del cuerpo igual que un ángel

que sale a desvalijar

los descabellados palacios de la noche

hasta llevarse nombres

vencidos, los nombres

que ya no nos merecemos,

se han librado del hueso

de sus significados, huelen a aliento pobre

y suenan, solo

suenan

en la gloria vacía de su cáscara, como esta tos que aún oigo, lejos,

reventar contra los parches indefensos de la noche.

(de Pérdida del ahí, 2016)

\section{Cuarto comentario}

El poema pertenece a la primera sección de Pérdida del ahí, titulada «La fruta está quieta». Toda ella trata de la generación, de la gestación de un poema. Desde la mudez — primer poema - hasta el último, «La llegada», que es la llegada del poema, por supuesto, expuesto en clave amorosa. La poesía comporta amor. Yo la entiendo así.

«Tos en la noche» quiere ser una especie de reflexión sobre el destino de las palabras malogradas, las palabras inmerecidas por los hombres. ¿Qué ocurre con esas palabras que no acaban de salir por nuestra boca? ¿Se convertirán en tos? La tos es eso. Ruidos atascados que en medio de la noche se oyen salir de una boca anónima, a través de los techos. Una vez más, reaparece el uso extraño de la lengua. Algo que no es ajeno a la lengua de un poema. Un poeta no acaba de saber 
nunca qué es lo que en último término está diciendo. Cuando leo mis poemas mucho tiempo después, siento esa sensación de ajenidad, de desamparo incluso. ¿Esa fue mi voz? ¿Ese era yo? ¿Qué quise decir? Entonces aplico el oído a lo que los lectores pueden decirme. Y en ocasiones, consigo pistas reveladoras sobre el sentido de algunos poemas, de algunas imágenes... Así lo decía en una de las respuestas de nuestra entrevista.

\section{Las cosas claras}

Presencias sumarísimas: la leche reventando como una barba blanca en la cazuela, la caída verdosa del aceite, el olor a contrariedad en la achicoria, la obscena liturgia de pelar las patatas, la fiebre de los ajos que arden como uñas por las afueras de tus manos,

tus manos actuando ahora hacia otra ganancia: la de las proporciones impecables.

Cosas claras de infancia. Tú entre todas.

(de Pérdida del ahí, 2016)

\section{Quinto comentario}

Las cosas tienen mucha importancia para mí. Podría decir que a veces tengo la impresión de que me interesan más que los seres vivos. Quizás en esa impresión vaya la certeza de que las cosas no mueren y uno se evita en su relación con ellas el drama de la pérdida. Rilke se refería a eso en aquellas Cartas a un joven poeta. Tengo muchos poemas dedicados a las cosas, a su compañía necesaria para mí, a su latido. Por ejemplo, «lo menudo» en Vida del topo. O en Pérdida del $a h i$, «Cosas que nos han seguido», donde se reflexiona sobre esos objetos que se quedan por su cuenta con nosotros a través de los años sin que los hayamos llamado, sin que ni siquiera los hayamos cuidado... Ellos nos siguen, mudanza tras mudanza, reaparecen cuando menos los esperamos, y convocan a quien nos las dejaron cerca.

«Las cosas claras» tiene ese doble sentido en el título (hay esa expresión que reclama claridad, sinceridad: «Las cosas claras y el chocolate, espeso», dice un dicho coloquial español. En el caso de este 
poema, hay una referencia a la infancia, otro de los ejes de mi poesía, cuando todo era epifanía, cuando no había sombras... Como se ve, el poema habla de cosas de la vida ordinaria, que es en último término una vida maravillosa, al menos para mí. El ambiente de una cocina, por ejemplo, esa intimidad de laboratorio donde conviven tantas cosas de los distintos reinos de la naturaleza... Me han definido en alguna ocasión como un cotidianista de la literatura, alguien que no acaba de creerse que haya que salir a buscar lo extraordinario fuera de la costumbre. Puede derrotarse a la costumbre ensayando siempre una mirada nueva sobre lo habitual ( La costumbre borra el verdadero rostro de las cosas», dejó dicho Montaigne, y es uno de los emblemas constantes de mi vida). De nuevo tengo que decir que esa convicción está muy presente en los intestinos de mi escritura: en los diarios - por ejemplo, en «Marcas», en el libro Para qué sirven los charcos- o en La vida mitigada; o en ciertos artículos donde evoco aquel latido de las cosas en el comercio de mi familia... La presencia de lo material me acompaña, me protege siempre. Así lo siento yo, al menos. 
